\title{
EXPERIMENTAL STUDY ON M50 GRADE OF HPC MIX USING HIGHLY REACTIVE METAKAOLIN AND RICE HUSK ASH WITH RECRON 3S FIBRE
}

\author{
Namrata Ray ${ }^{1}$, Pravat Kumar Parhi ${ }^{2}$ \\ ${ }^{I}$ P.G.Student, Department of Civil Engineering, College of Engineering and Technology, BBSR \\ ${ }^{2}$ Professor, Civil Engineering Department, College of Engineering Technology, BBSR
}

\begin{abstract}
Concrete is one of the most durable building material and versatile in nature used for making many structures worldwise. In this technological world construction industries need to plan for effective utilization of waste materials(both natural and industrial byproduct) for improving production of concrete economically and aesthetically. For improving properties of concrete and to minimize use of cement which is a major component of concrete, partial replacement of cement is required as Global cement production is expected to increase from 3.27 billion metric tons in 2010 to 4.83 billion metric tons in 2030 which has a bad impact on environment .Cement production emits harmful $\mathrm{CO}_{2}$ gas leading to global warming, health disorders and so on. Earlier studies has shown that when Rice Husk Ash(RHA) used as partial cement supplement gradual decrease in strength is seen. Here experimental investigation has been carried out with respect to strength and durability study and other mechanical properties study on performance of HPC of M50 grade of concrete using HRM and RHA as partial replacement of cement with addition of Recron 3s fibre by weight of concrete. Recron 3s fibre controls and arrest cracks in concrete. Highly Reactive Metakaolin(HRM) which is a very reactive material used in different percentage (5\%,10\%,15\% and $20 \%)$ along with constant $5 \%$ RHA and constant 7.5\% RHA with addition of $0.2 \%$ Recron 3 s fibre $(R F)$ by weight of concrete for producing better modified concrete . Various strength parameters like compressive strength, split tensile strength and flexural strength are studied. Water absorption and Porosity test are also presented experimentally in this paper.From the experimental study, it was observed that when HRM and RHA are used as partial replacement of cement with addition of recron $3 \mathrm{~s}$ fibre to weight of concrete, it improves the mechanical properties specially the porosity and water absorption decreases and gradual increase and then decease in compressive, split tensile, flexural strength.
\end{abstract}

Keywords: RHA, Highly Reactive Metakaolin, Recron 3s fibre, HPC mix, Durability, mechanical properties

\section{INTRODUCTION}

Concrete is a quasi-brittle material (according to modern fracture mechanics) and heterogeneous mixture of cement, fine aggregate, coarse aggregate and water. Concrete being weak in tensile strength, to make structures strong and durable there is a great need to increase and enhance the mechanical properties like strength, durability, toughness, hardness, fatigue resistance along with physical properties like density, thermal conductivity which all alone cannot be achieved using plain concrete. So HPC mix is used which can enhance performance of concrete. High degree of quality control is required for HPC mix with lower w/c ratio and use of high range water reducer. Use of Highly Reactive Metakaolin as partial replacement of cement which is produced by calcination of pure Kaolinitic clays at a temperature between $\left(650^{\circ} \mathrm{C}-850^{\circ} \mathrm{C}\right)$ widely available in the earth's crust. It improves the mechanical properties of concrete and ecofriendly in nature as does not produce harmful $\mathrm{CO}_{2}$ gas. It's low overall cost due to less damage to structure,longer life service in severe environment, decreased porosity, early strength achievement, reduces maintenance, densifies concrete and reduces the thickness of the interfacial zone which improves proper mixing between cement paste and sand particles make it best material to be used as partial replacement of cement. RHA is a natural waste product about $25 \%$ by weight of rice husk when burnt in boilers contains $89 \%$ of amorphous silica. Rice husk produced annually about 20 million tones which comes from field during paddy milling from rice milling industry. RHA has high concentration of silica, generally more than 80$85 \%$ according to estimation. Recron $3 \mathrm{~s}$ fibre used as secondary reinforcement to prevent shrinkage cracks and propagate cracks by supporting in all directions and speed up the construction work and also used for shotcrete, plastering, prestressed beams, bridges, dams etc. From previous researches we know the strength varies slightly from normal concrete when $0.1 \% \mathrm{RF}$ and $0.3 \% \mathrm{RF}$ are used.But best resultin strength improvement was seen using constant $0.2 \% \mathrm{RF}$ additionso $0.2 \% \mathrm{RF}$ by weight of concrete addition is used in concrete with HRM and RHA. When HRM and RHA both are used as partial replacement of cement with addition of recron3s fibre the results were analyzed properly. Durability test such as water absorption and porosity test at 28 days curing was also done experimentally. M50 grade of concrete is used with constant w/c ratio of 0.35 


\section{MATERIALS AND PROPERTIES}

\subsection{Cement}

Cement is the basic ingredient of concrete mixture. A cement acts as a binder, to bind the fine and the coarse aggregate together and to fill the voids in between fine and coarse aggregates particles to form a compact mass. For present thesis paper, Ordinary Portland Cement (OPC) of 53 grade was used specifying all the properties from IS122691987. The brand of cement used was Coramendel King. The use of high grade cement saves cement requirement with high strength achievement.For various laboratory tests of cement following tests have been carried out according to IS: 8112 - 1989 and presented in table1 describing the physical properties of OPC 53 grade. From table1 we can compare properties obtained from experimental studies and actual requirement according to IS 12269:2013 specification.

Table1: Physical properties of OPC

\begin{tabular}{|c|c|c|c|}
\hline $\begin{array}{l}\text { SL. } \\
\text { NO } \\
.\end{array}$ & $\begin{array}{l}\text { Characteristi } \\
\text { cs }\end{array}$ & $\begin{array}{l}\text { Value } \\
\text { obtained } \\
\text { experime } \\
\text { ntally }\end{array}$ & $\begin{array}{l}\text { Requirement } \\
\text { as IS } \\
12269: 2013 \\
\text { specification }\end{array}$ \\
\hline 1 & Grade & 53 & \\
\hline 2 & $\begin{array}{l}\text { Normal } \\
\text { Consistency }\end{array}$ & 32 & --------- \\
\hline 3 & $\begin{array}{l}\text { Initial setting } \\
\text { time(min) }\end{array}$ & $80 \mathrm{~min}$ & $\begin{array}{l}\text { 30min (minimu } \\
\mathrm{m}\end{array}$ \\
\hline 4 & $\begin{array}{l}\text { Final setting } \\
\text { time(min) }\end{array}$ & $410 \mathrm{~min}$ & $\begin{array}{l}600 \min (\operatorname{maxim} \\
\text { um) }\end{array}$ \\
\hline 5 & $\begin{array}{l}\text { Compressive } \\
\text { strength at } 3 \\
\text { days }(\mathrm{MPa})\end{array}$ & $\begin{array}{l}30.2 \\
\mathrm{~N} / \mathrm{mm}^{2}\end{array}$ & $27.0 \mathrm{~N} / \mathrm{mm}^{2}$ \\
\hline 6 & $\begin{array}{l}\text { Compressive } \\
\text { strength at } 7 \\
\text { days }(\mathrm{MPa})\end{array}$ & $\begin{array}{l}42.7 \\
\mathrm{~N} / \mathrm{mm}^{2}\end{array}$ & $37.0 \mathrm{~N} / \mathrm{mm}^{2}$ \\
\hline 7 & $\begin{array}{l}\text { Compressive } \\
\text { strength at } 28 \\
\text { days }(\mathrm{MPa})\end{array}$ & $\begin{array}{l}57.8 \\
\mathrm{~N} / \mathrm{mm}^{2}\end{array}$ & $53.0 \mathrm{~N} / \mathrm{mm}^{2}$ \\
\hline 8 & $\begin{array}{l}\text { Soundness:B } \\
\text { y Le chatelier } \\
\text { method }\end{array}$ & $9.8 \mathrm{~mm}$ & $10 \mathrm{~mm}$ \\
\hline
\end{tabular}

\subsection{Fine Aggregate and Coarse Aggregate}

The sand which is used in this experimental investigation is confirming to grading zone II of Table 4 of IS 383-1970 and has been collected from locally. Most of the aggregate passes through a $4.75 \mathrm{~mm}$ IS sieve and contains only that much coarser material as is permitted by the specification. Sand is generally considered to have a lower size limit of about $0.07 \mathrm{~mm}$. According to size the fine aggregate may be described as coarse medium and fine sand. The fineness modulus may be taken as guidance for making satisfactory concrete.The object of finding the fineness modulus is to grade the given aggregate for obtaining a most economical and workable mix with minimum quantity of cement. The minimum limit of fineness modulus of fine aggregate is 2.0 and maximum limit is 3.5. The sieve analysis has been conducted to determine the FM and grading Zone. The locally available Crushed aggregate with $50 \%$ passing through $12.5 \mathrm{~mm}$ and retained on $10 \mathrm{~mm}$ sieve and $50 \%$ passing through $20 \mathrm{~mm}$ and retained on $12.5 \mathrm{~mm}$ sieve was used. The following tests have been carried out as per the procedure given in IS 383-1970 and IS.2386-1963 and the results are presented below in table 2 describing properties of aggregate.

Table2: Properties of aggregates

\begin{tabular}{|l|l|l|l|}
\hline Sl.No. & $\begin{array}{l}\text { Properties } \\
\text { of } \\
\text { aggregate }\end{array}$ & $\begin{array}{l}\text { Fine } \\
\text { aggregate }\end{array}$ & $\begin{array}{l}\text { Coarse } \\
\text { aggregate }\end{array}$ \\
\hline 1 & $\begin{array}{l}\text { Specific } \\
\text { Gravity }\end{array}$ & 2.61 & 2.65 \\
\hline 2 & $\begin{array}{l}\text { Fineness } \\
\text { modulus }\end{array}$ & 2.77 & 6.76 \\
\hline 3 & $\begin{array}{l}\text { Water } \\
\text { absorption }\end{array}$ & $0.8 \%$ & $0.7 \%$ \\
\hline
\end{tabular}

\subsection{Highly Reactive Metakaolin (HRM)}

The particle size of Metakaolin is significantly smaller than cement particles. Blending of Metakaolin with cement improves the mechanical properties of concrete. The pozzolanic reaction between Metakaolin and the $\mathrm{C}-\mathrm{H}$ produced by the hydration of thecement enhanced the early strength. Usage of Metakaolin can be more advantageous for preparing stronger and more durable concrete mixes due to above reasons. The performance of concrete is substantially improved by using Metakaolin. Here, the physical properties of Highly Reactive Metakaolin(HRM) has been experimentally discussed. Metakaolin used for present experimental work was obtained from Navpad Sales, Pozzocrete distributor, Surat, Gujarat.Specific Gravity of HRM was found to be 2.72 .

\subsection{RHA}

Rice husk ash is obtained by burning rice husk obtained from paddy mill at a controlled high temperature without causing environmental pollution much. When it is properly brunt it's high $\mathrm{SiO}_{2}$ content and can be used as a concrete admixture. Rice husk ash exhibits high pozzolanic characteristics and contributes to better strength and high impermeability of concrete.From previous experimental results we know that Rice husk ash consists of amorphous or non-crystalline silica with about $85-90 \%$ cellular particle, $5 \%$ carbon and $2 \% \mathrm{~K}_{2} \mathrm{O}$. India produces about 122 million ton of paddy each day. Each ton of paddy produces about 40 $\mathrm{kg}$ of RHA. There is a good potential to make use of RHA as a valuable pozzolanic material to give almost the same properties as that of micro silica. From experimental investigation the properties of RHA is shown in table3.

Table3: shows properties of RHA

\begin{tabular}{|l|l|}
\hline Physical state & Solid-Non Hazardous \\
\hline Appearance & Very fine powder \\
\hline Colour & Grey \\
\hline Odour & Odourless \\
\hline Specific Gravity & 2.3 \\
\hline
\end{tabular}




\subsection{Recron 3s Fibre}

Recron $3 \mathrm{~s}$ fibre are manufactured by Reliance Industries limited(RIL), V.P.O.Chohal, Hoshiarpur, Punjab, India an associate company of Reliance Industries Limited(RIL)

Properties of recron 3s fibre:

Colour:- Brilliant White

Length Cut:- $12 \mathrm{~mm}$

Dispersion:- Excellent

Acid resistance:- Excellent

\section{EXPERIMENTAL WORK AND TESTS}

\subsection{Mix Design}

HPC of M50 grade of concrete was designed as per standard specification IS: 10262-2009 to achieve target mean strength of 58.25MPa respectively. The detailed mix design ratio and material calculation for $1 \mathrm{~m}^{3}$ of concrete are given in table 4 below:

Table4 : Mix proportion for $1 \mathrm{~m}^{3}$ of M50 HPC mix

\begin{tabular}{|l|l|}
\hline Material Mix & M50 \\
\hline Cement & $444.96 \mathrm{~kg}$ \\
\hline Fine aggregate & $621 \mathrm{~kg}$ \\
\hline Coarse aggregate & $1284 \mathrm{~kg}$ \\
\hline Water/cement ratio & 0.35 \\
\hline Ratio & $1: 1.395: 2.885$ \\
\hline
\end{tabular}

\subsection{Methodology of our Study}

\subsubsection{Compressive Strength:-C=P/A}

Where, $\mathrm{P}=$ load in Newton

$\mathrm{A}=$ area of cross section of cube in $\mathrm{mm}^{2}$

\subsubsection{Splitting Tensile Strength :-S $=2 \mathrm{P} / \pi \times \mathbf{l} \times \mathbf{d}$}

Where, $\mathrm{P}=$ load in Newton

$\mathrm{l}=$ length of cylinder in $\mathrm{mm}$ i.e. $300 \mathrm{~mm}$

$\mathrm{d}=$ diameter of cylinder in $\mathrm{mm}$ i.e $150 \mathrm{~mm}$

\subsubsection{Flexural Strength:-F=PI/bh ${ }^{2}$}

Where, $\mathrm{P}=$ load in Newton shown in dial gauge $\mathrm{l}=$ length of rectangular prism in $\mathrm{mm}$ i.e. $400 \mathrm{~mm}$ $\mathrm{b}=$ breadth of rectangular prism i.e. $100 \mathrm{~mm}$

\subsubsection{Durability Tests}

\subsubsection{Water absorption of Specimen}

Water absorption test was determined on specimen of size $150 \times 150 \times 150 \mathrm{~mm}^{3}$ concrete cube at 28 days curing age as per ASTM C-642(1997) by drying the specimen in an oven temperature and taking weight and after cooling again keeping in water for absorption

\section{Water absorption $=($ Saturated mass-Oven dry mass $) /$ Oven} dry mass $\times 100$

\subsubsection{Porosity}

Porosity of a rock is a measure of its capacity to contain or store fluids.Water absorption of concrete is a measure of porosity in hardened concrete occupied by water in saturated condition. The porosity obtained from water absorption tests is termed as effective porosity. It is determined using the following formula:Effective Porosity $=$ Pore Volume/Bulk volume of specimen $\times 100$

$$
\text { Effective porosity, } \mathrm{p}=\left(\mathrm{W}_{\mathrm{s}}-\mathrm{W}_{\mathrm{d}}\right) /\left(\mathrm{W}_{\mathrm{s}}-\mathrm{W}_{\text {sub }}\right) \times 100
$$

Where, $\mathrm{W}_{\mathrm{s}}=$ Weight of specimen at fully saturated condition

$\mathrm{W}_{\mathrm{d}}=$ Weight of specimen at oven dried condition

$\mathrm{W}_{\text {sub }}=$ Weight of specimen when submerged in water.

The test for porosity was carried out on $150 \mathrm{~mm} \times 150 \mathrm{~mm} \times 150 \mathrm{~mm}$ HPC cube specimen according to the above formula described above.

\subsection{Slump Cone Test}

Workability is the amount of work to produce full compaction. Workability is used to describe the ease or difficulty with which the concrete is transported, handled and placed between the forms. The slump test is commonly used in the field. The difference level between the height of the mould and that of the highest point of the subsided concrete is measured. The slump test values are written in Table 5 and shown in figure 1 below:

Table 5: Variation in slump for determining workability

\begin{tabular}{|l|l|}
\hline $\begin{array}{l}\% \text { of HRM } \\
+5 \% \text { RHA+0.2\%RF } \\
\text { addition }\end{array}$ & Slump $(\mathrm{mm})$ \\
\hline 0 & 75 \\
\hline 5 & 60 \\
\hline 10 & 50 \\
\hline 15 & 45 \\
\hline 20 & 40 \\
\hline
\end{tabular}




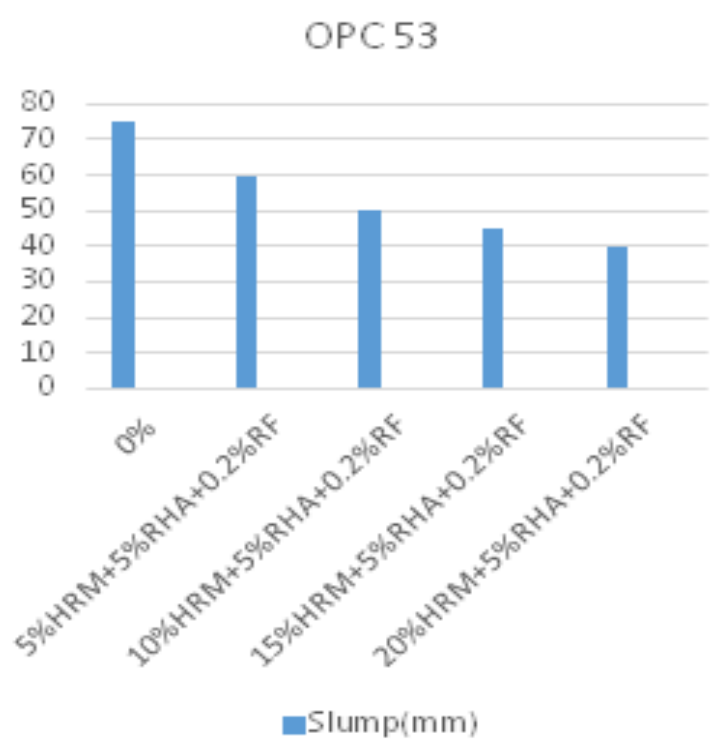

Fig 1 shows the variation of slump value

\section{RESULTS WITH DISCUSSION}

\subsection{Compressive Strength}

A set of 3 concrete cubes $(150 \mathrm{~mm} \times 150 \mathrm{~mm} \times 150 \mathrm{~mm})$ casted and tested each after 7 and 28 days for each mix proportion to determine the Compressive strength and make a comparison between conventional concrete and $\operatorname{HRM}(\%)$ and $\operatorname{RHA}(\%)$ with recron $3 \mathrm{~s}$ fibre as partial replacement of cement.Here cement is replaced partially by combining HRM with different percentages $5 \%, 10 \%, 15 \%$ and $20 \%$ and RHA with $5 \%$ only with constant addition of $0.2 \%$ RF and then HRM and $7.5 \%$ RHA with $0.2 \%$ RF addition. Here the test was carried out by keeping constant $\mathrm{w} / \mathrm{c}$ ratio 0.35 and admixture of $1.2 \%$ by weight of cement was used here.The variation in compressive strength of cube mould is writteninTable6 and shown in figure2.

Table 6: Variation in Compressive strength

\begin{tabular}{|c|c|c|c|c|}
\hline \multirow[t]{2}{*}{$\begin{array}{l}\mathrm{HR} \\
\mathrm{M}\end{array}$} & \multicolumn{2}{|c|}{$\begin{array}{l}\mathrm{HRM}(\%) \quad \text { WITH } \\
5 \% \mathrm{RHA}+0.2 \% \mathrm{RF}\end{array}$} & \multicolumn{2}{|c|}{$\begin{array}{l}\operatorname{HRM}(\%) \quad \text { WITH } \\
7.5 \% \text { RHA+0.2\%RF }\end{array}$} \\
\hline & $\begin{array}{l}7 \quad \text { days } \\
\text { Compres } \\
\text { sive } \\
\text { strength }( \\
\left.\mathrm{N} / \mathrm{mm}^{2}\right)\end{array}$ & $\begin{array}{l}28 \text { days } \\
\text { Compres } \\
\text { sive } \\
\text { strength } \\
\mathrm{N} / \mathrm{mm}^{2}\end{array}$ & $\begin{array}{l}7 \quad \text { days } \\
\text { Compres } \\
\text { sive } \\
\text { strength } \\
\mathrm{N} / \mathrm{mm}^{2}\end{array}$ & $\begin{array}{l}28 \text { days } \\
\text { Compressiv } \\
\text { e strength } \\
\mathrm{N} / \mathrm{mm}^{2}\end{array}$ \\
\hline $\begin{array}{l}\mathrm{CC} 0 \\
\%\end{array}$ & 46.66 & 60.88 & 46.66 & 60.88 \\
\hline $5 \%$ & 47.55 & 63.68 & 47.02 & 62.88 \\
\hline $10 \%$ & 49.64 & 65.46 & 49.11 & 64.87 \\
\hline $15 \%$ & 45.54 & 60.44 & 44.84 & 61.32 \\
\hline $20 \%$ & 43.95 & 58.66 & 42.17 & 58.23 \\
\hline
\end{tabular}

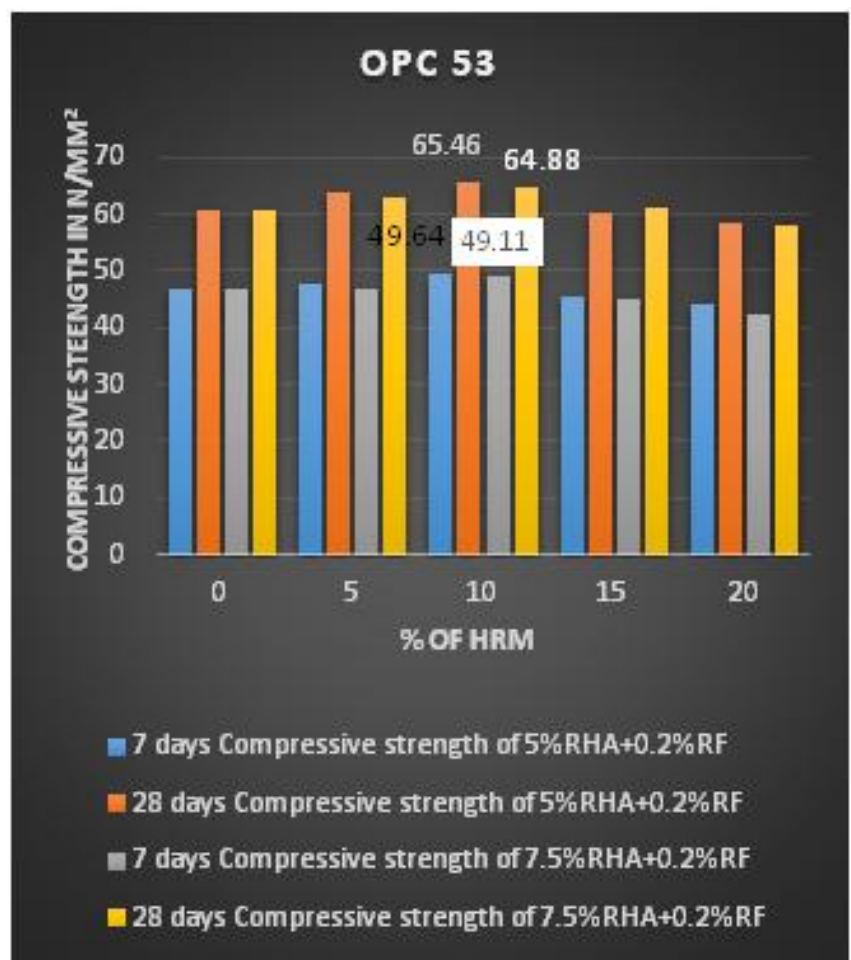

Fig 2 shows the variation in Compressive strength

\subsection{Splitting Tensile Strength}

Cylindrical specimens of $300 \mathrm{~mm}$ long and $150 \mathrm{~mm}$ diameter were tested in Compression testing machine. The results of split tensile strength test of cylinder for 7 and 28 days of curing are given in the Table 5 shows the comparison of split tensile strength of Conventional concrete and partial replacement of Cement with $\operatorname{RHA}(5 \%)$ with different percentages of HRM $(5 \%, 10 \%, 15 \%$ and $20 \%)$ with $0.2 \% \mathrm{RF}$ additionand partial replacement of Cement with $\operatorname{RHA}(7.5 \%)$ with different percentages of $\operatorname{HRM}(5 \%, 10 \%$, $15 \%$ and $20 \%$ ) with $0.2 \% \mathrm{RF}$ addition and making a comparison between them and observing the variation of splitting tensile strength from table7 and figure 3 below:

Table 7: Variation in splitting tensile strength

\begin{tabular}{|c|c|c|c|c|}
\hline \multirow[t]{2}{*}{$\begin{array}{l}\mathrm{HRM} \\
\%\end{array}$} & \multicolumn{2}{|c|}{$\begin{array}{l}\text { HRM }(\%) \quad \text { WITH } \\
5 \% \text { RHA+0.2\%RF }\end{array}$} & \multicolumn{2}{|c|}{$\begin{array}{l}\operatorname{HRM}(\%) \quad \text { WITH } \\
7.5 \% \text { RHA+0.2\%RF }\end{array}$} \\
\hline & $\begin{array}{l}7 \text { days } \\
\text { Splitting } \\
\text { Tensile } \\
\text { strength }\end{array}$ & $\begin{array}{l}28 \text { days } \\
\text { Splitting } \\
\text { Tensile } \\
\text { strength }\end{array}$ & $\begin{array}{l}7 \text { days } \\
\text { Splitting } \\
\text { Tensile } \\
\text { strength }\end{array}$ & $\begin{array}{l}28 \text { days } \\
\text { Splitting } \\
\text { Tensile } \\
\text { strength }\end{array}$ \\
\hline 0 & 4.36 & 6.54 & 4.36 & 6.54 \\
\hline 5 & 4.796 & 6.106 & 3.924 & 6.976 \\
\hline 10 & 5.232 & 6.976 & 4.796 & 6.104 \\
\hline 15 & 3.488 & 5.232 & 3.488 & 5.232 \\
\hline 20 & 3.052 & 4.36 & 2.616 & 3.052 \\
\hline
\end{tabular}




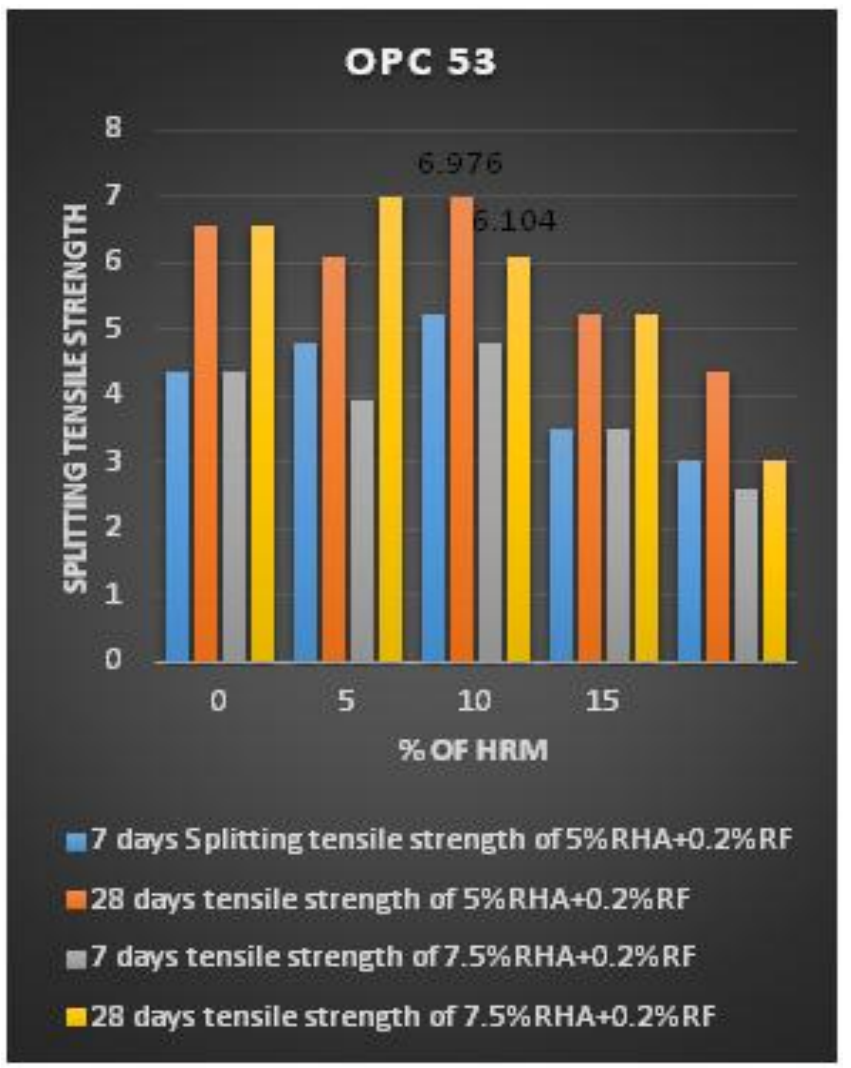

Fig 3 shows variation in Splitting tensile strength

\subsection{Flexural Strength}

Prismatic specimens $100 \times 100 \times 500 \mathrm{~mm}^{3}$ were tested according to IS:516(1959). The results of Flexural strength of prisms for 7 and 28 days of curing are given in Table8. The figure4 shows the comparisons of Flexural strength of conventional concrete and replacement of cement with $\mathrm{RHA}(5 \%)$ and $\mathrm{HRM}(\%)$ with constant $0.2 \% \mathrm{RF}$ addition for 7 and 28 days of curing respectively and replacement of cement with RHA(7.5\%) and HRM with constant $0.2 \%$ RF addition for 7 and 28 days of curing respectively

Table 8: Variation of flexural strength

\begin{tabular}{|c|c|c|c|c|}
\hline \multirow[t]{2}{*}{ HRM } & \multicolumn{2}{|c|}{$\begin{array}{l}\text { HRM(\%) WITH } \\
5 \% \text { RHA+0.2\%RF }\end{array}$} & \multicolumn{2}{|c|}{$\begin{array}{l}\operatorname{HRM}(\%) \quad \text { WITH } \\
7.5 \% \text { RHA+0.2\%RF }\end{array}$} \\
\hline & $\begin{array}{l}7 \quad \text { days } \\
\text { Flexural } \\
\text { strength } \\
\left(\mathrm{N} / \mathrm{mm}^{2}\right. \\
)\end{array}$ & $\begin{array}{l}28 \text { days } \\
\text { Flexural } \\
\text { strength }(\mathrm{N} \\
\left./ \mathrm{mm}^{2}\right)\end{array}$ & $\begin{array}{l}7 \quad \text { days } \\
\text { Flexural } \\
\text { strength }( \\
\left.\mathrm{N} / \mathrm{mm}^{2}\right)\end{array}$ & $\begin{array}{l}28 \text { days } \\
\text { Flexural } \\
\text { strength }(\mathrm{N} \\
\left./ \mathrm{mm}^{2}\right)\end{array}$ \\
\hline $0 \% \mathrm{NC}$ & 8 & 12 & 8 & 12 \\
\hline $5 \%$ & 8.9 & 12.4 & 8.4 & 12.4 \\
\hline $10 \%$ & 9.6 & 13.6 & 9.2 & 13.2 \\
\hline $15 \%$ & 7.6 & 11.6 & 7.2 & 11.2 \\
\hline $20 \%$ & 6.8 & 10.8 & 6.8 & 10.4 \\
\hline
\end{tabular}

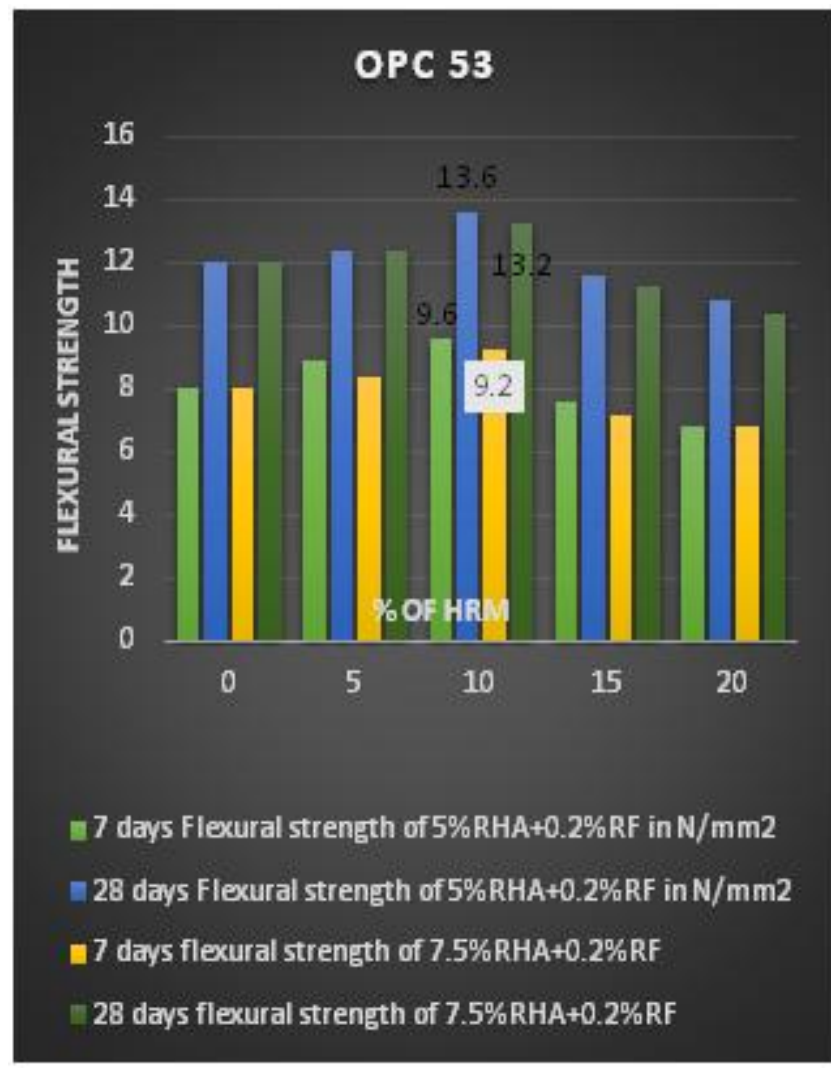

Fig 4 shows variation in Flexural strength

\subsection{Water Absorption}

When HRM with different percentage and 5\%RHA is used as partial replacement of cement with $0.2 \%$ recron 3 s fibre addition the variation in water absorption of concrete cube moulds at 28 days is written in table 9 and shown in figure5.

Table 9: Variation in water absorption after partially

\begin{tabular}{|l|l|l|l|l|}
\hline $\begin{array}{l}\text { Replaceme } \\
\text { nt by } \\
\text { HRM+RF } \\
\text { addition }\end{array}$ & $\begin{array}{l}\text { RHA } \\
\%\end{array}$ & $\begin{array}{l}\text { Wet } \\
\text { weightk } \\
\mathrm{g}\end{array}$ & $\begin{array}{l}\text { Dry } \\
\text { weightk } \\
\mathrm{g}\end{array}$ & $\begin{array}{l}\text { Water } \\
\text { absorption( } \\
\%)\end{array}$ \\
\hline 0 & 0 & 2.546 & 2.463 & 3.42 \\
\hline $5 \%+0.2 \%$ & 5 & 2.483 & 2.434 & 2.01 \\
\hline $10 \%+0.2 \%$ & 5 & 2.574 & 2.533 & 1.62 \\
\hline $15 \%+0.2 \%$ & 5 & 2.600 & 2.502 & 3.91 \\
\hline $20 \%+0.2 \%$ & 5 & 2.580 & 2.489 & 3.99 \\
\hline
\end{tabular}




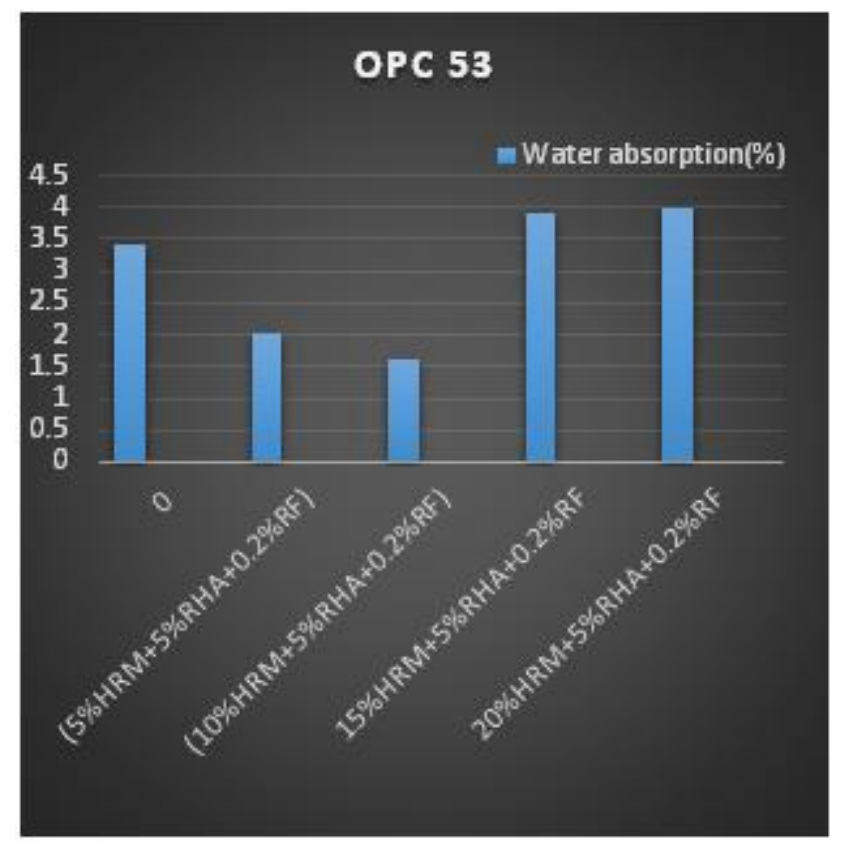

Fig 5 shows variation in water absorption at 28 days

\subsection{Porosity}

When HRM with different percentage and 5\%RHA is used as partial replacement of cement with $0.2 \%$ recron $3 \mathrm{~s}$ fibre addition the variation in porosity of concrete cube moulds at 28 days is written in table10and shown in figure6.

Table 10: Variation of porosity of concrete

\begin{tabular}{|l|l|l|l|l|}
\hline $\begin{array}{l}\text { HRM+RF } \\
\text { addition+ } \\
\text { RHA }\end{array}$ & $\begin{array}{l}\text { Dry } \\
\text { weight } \\
\text { in kg }\end{array}$ & $\begin{array}{l}\text { Saturated } \\
\text { weight in } \\
\mathrm{kg}\end{array}$ & $\begin{array}{l}\text { Subme } \\
\text { rged } \\
\text { weight } \\
\mathrm{kg})\end{array}$ & $\begin{array}{l}\text { Porosity } \\
\text { at 28 } \\
\text { days(\%) }\end{array}$ \\
\hline $0 \%$ & 2.470 & 2.506 & 1.25 & 2.86 \\
\hline $\begin{array}{l}5 \%+0.2 \%+ \\
5 \%\end{array}$ & 2.560 & 2.587 & 1.25 & 2.02 \\
\hline $\begin{array}{l}10 \%+0.2 \% \\
+5 \%\end{array}$ & 2.562 & 2.590 & 1.25 & 2.08 \\
\hline $\begin{array}{l}15 \%+0.2 \% \\
+5 \%\end{array}$ & 2.52 & 2.560 & 1.25 & 3.05 \\
\hline $\begin{array}{l}20 \%+0.2 \% \\
+5 \%\end{array}$ & 2.544 & 2.590 & 1.25 & 3.432 \\
\hline
\end{tabular}

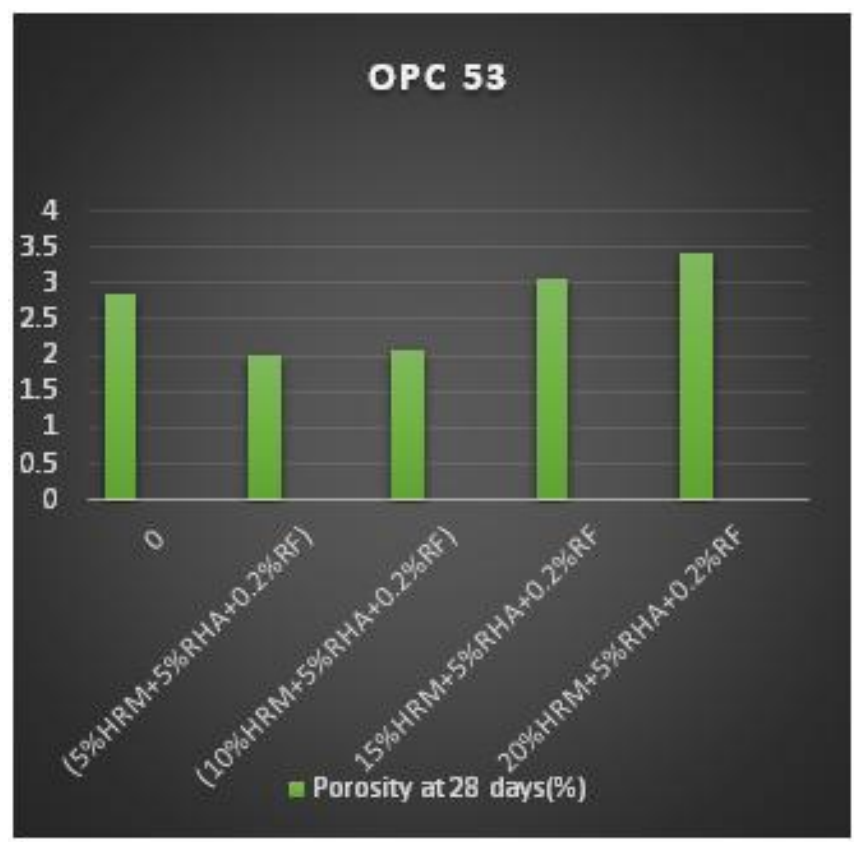

Fig 6 shows variation in porosity at 28 days

\section{CONCLUSION}

From the laboratory investigation and experimental program held in laboratory following conclusions are drawn:

1. When HRM and RHA are used as partial replacement of cement with Recron $3 \mathrm{~s}$ fibre addition early increase in compressive strength within 7 days more than conventional concrete by about $6.38 \%$ is seen. Similarly, about $10 \%$ increase in split tensile and $11 \%$ increase in flexural strength is observed.

2. It was observed that for conventional M50 grade of HPC mix the compressive strength in 28 days was more than target mean strength $\left(58.25 \mathrm{~N} / \mathrm{mm}^{2}\right)$,increasing by 4.54 i.e. $60.88 \mathrm{~N} / \mathrm{mm}^{2}$ by using OPC 53 grade with w/c ratio 0.35

3. With the use of superplasticizer(Sika) it is possible to get a mix with low water/cement ratio (i.e0.35) to get the desired strength and durability results.

4. Using HPC mix for M50 grade there was an early gain of strength about $46.66 \mathrm{~N} / \mathrm{mm} 2$ for compressive strength, $4.36 \mathrm{~N} / \mathrm{mm} 2$ for splitting tensile strength, $8 \mathrm{~N} / \mathrm{mm} 2$ for Flexural strength

5. But when partial replacement of cement by HRM and constant 5\%RHA with small quantity of $0.2 \%$ RF by weight of concrete addition the results were just amazing an increase of $7.5 \%$ in compressive strength to normal strength was seen till $10 \%$ partial replacement of cement then gradual decrease in strength was observed but still more than normal strength.

6. Similarly about $6.66 \%$ in splitting tensile and $13.33 \%$ in flexural strength to conventional concrete was seen till $10 \%$ replacement the after a large decrease in strength was seen in $20 \%$ replacement but more than conventional concrete

7. When partial replacement of cement done by $\mathrm{HRM}$ (with different percentage) and constant $7.5 \%$ 
RHA with $0.2 \%$ RF addition by weight of concrete increase in strength was seen upto $10 \% \mathrm{HRM}$ replacement then after gradual decrease in strength is observed

8. When water absorption test was done amazing results were obtained by using $\operatorname{HRM}(\%), 5 \%$ RHA with $0.2 \% \mathrm{RF}$, there was a decrease in water absorption

9. Decrease in water absorption was seen when $5 \%$ and $10 \%$ HRM was used with 5\%RHA with small quantity of $0.2 \%$ RF by weight of concrete addition in it.

10. Maximum increase in compressive strength, split tensile strength and flexural strength occurred at $10 \% \mathrm{HRM}$ and $5 \%$ RHA with small quantity of $0.2 \% \mathrm{RF}$ by weight of concrete addition as partial replacement of cement.

11. Decrease in porosity was seen when $5 \%$ and $10 \%$ HRM was used with 5\%RHA with $0.2 \% \mathrm{RF}$ addition in it and after $10 \%$ replacement a slight increase in porosity is seen

12. Workability decreases as we increase replacement by $\mathrm{HRM}$ (with different percentages) and $\operatorname{RHA}(5 \%)$ and recron $3 \mathrm{~s}$ fibre addition

13. Maximum increase in compressive strength, split tensile strength and flexural strength occurs at $10 \% \mathrm{HRM}$ and $5 \%$ RHA with $0.2 \%$ RF addition.

\section{REFERENCES}

[1] M.L.Gambhir,"Concrete Technology", $4^{\text {th }}$ edition, The Mc Graw-Hill Private Limited

[2] IS 456 : 2000,'Indian Standard Code of Practice for plain and Reinforced Concrete," Bureau of Indian Standard, New Delhi, 2000

[3] IS 10262 : 2009,"Concrete Mix ProportioningGuidelines,"Bureau of Indian Standard, New Delhi

[4] IS $5816: 1999$, ,'Splitting tensile strength of Concrete methods of test," Bureau of Indian Standard, New Delhi

[5] Rangwala," Engineering Materials[MATERIAL SCIENCE]", Charotar Publising House Private Limited

[6] IS 9103 : 1999,'"Indian Standard concrete Admixture specification," Bureau of Indian Standard, New Delhi

[7] M. S. Shetty, 2002, "Concrete Technology and Practice", S. Chand company

[8] Sandeep.T.,2015,Recron Medium Strength Fibre Reinforced Concrete, International journal

\section{PHOTO GALLERY}

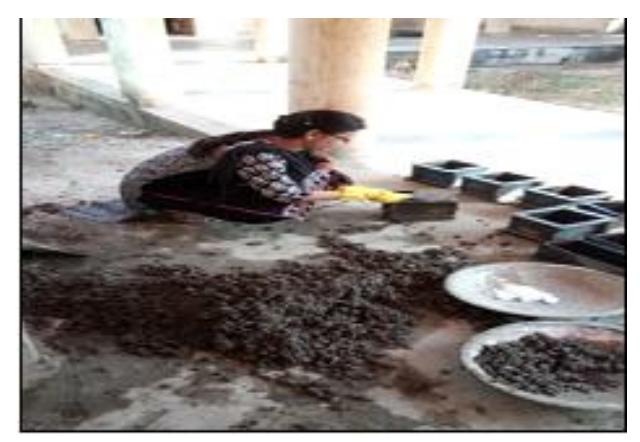

Casting of moulds

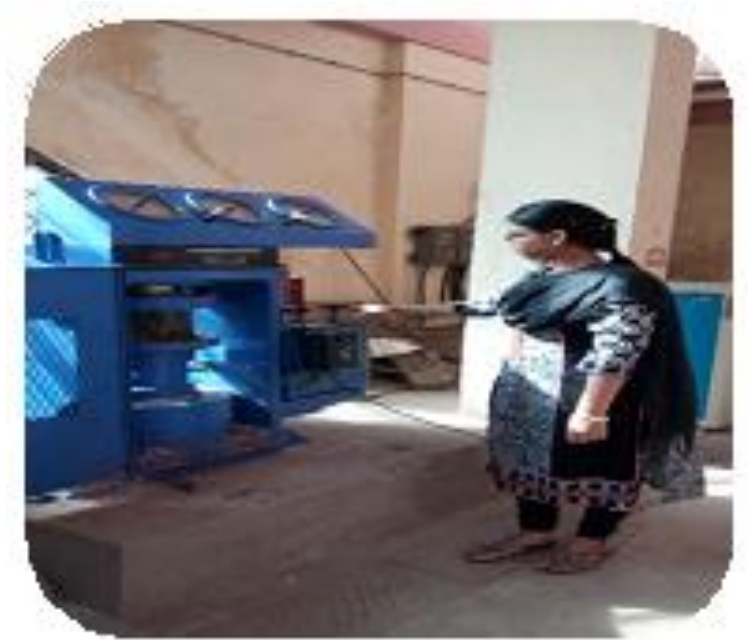

Compressive strength test after failure

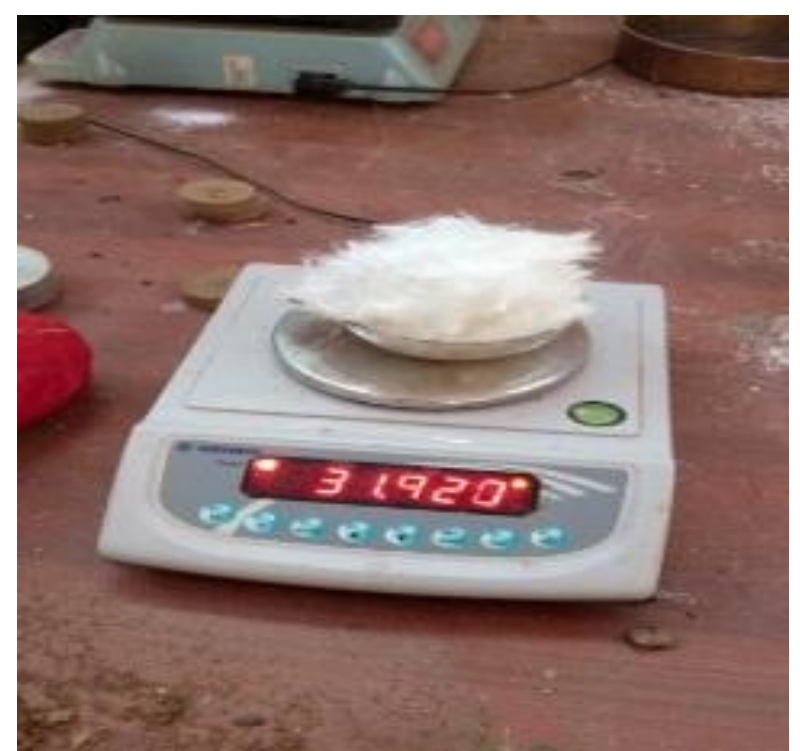

Reron 3s fibre on weight machine

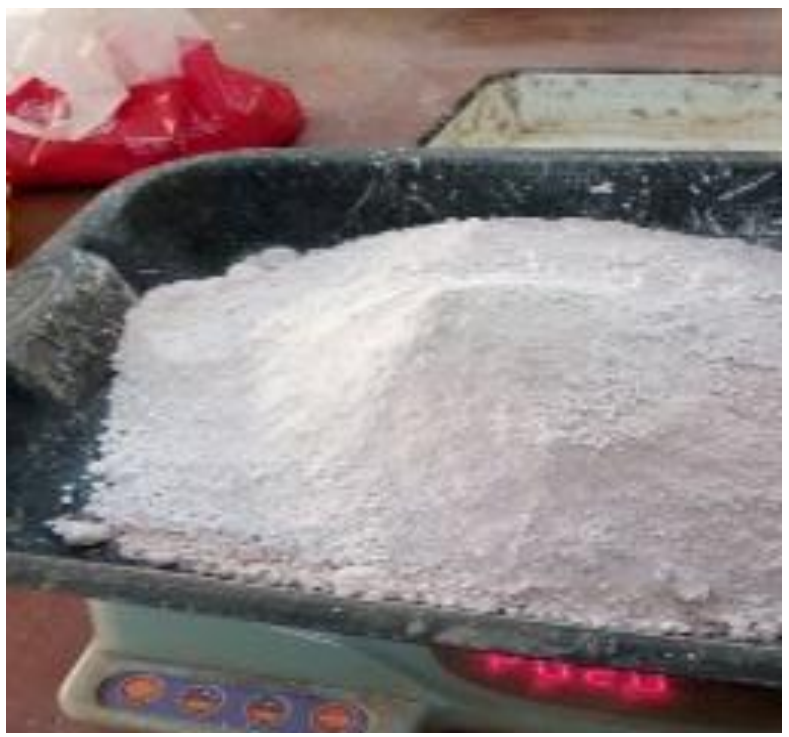

Highly Reactive Metakaolin 


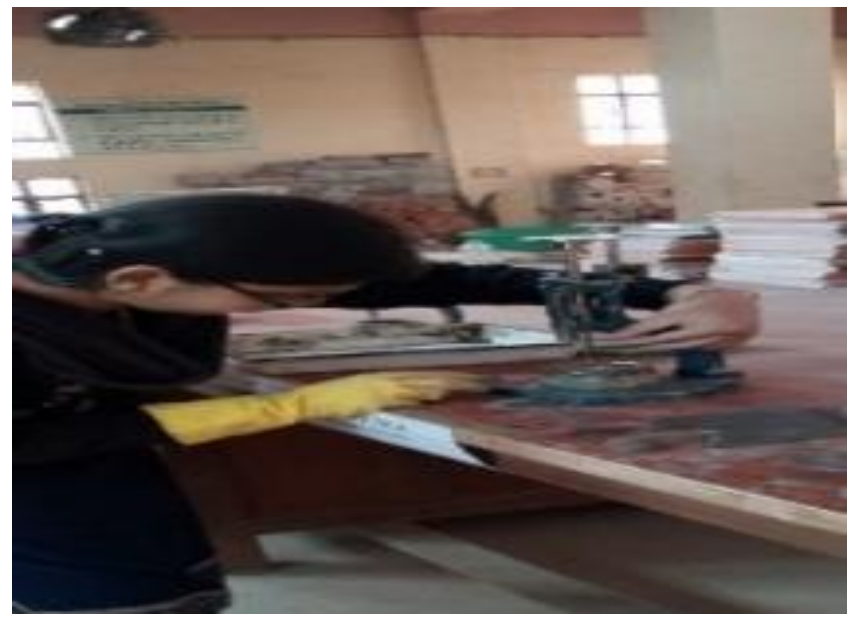

Vicat apparatus for initial setting time 